University at Buffalo School of Law

Digital Commons @ University at Buffalo School of Law

2013

\title{
The Culture of Financial Institutions: The Institution of Political Economy
}

David A. Westbrook

University at Buffalo School of Law, dwestbro@buffalo.edu

Follow this and additional works at: https://digitalcommons.law.buffalo.edu/book_sections

Part of the Law and Economics Commons

\section{Recommended Citation}

David A. Westbrook, The Culture of Financial Institutions: The Institution of Political Economy in Integrity, Risk and Accountability in Capital Markets: Regulating Culture 1 (Justin O'Brien \& George Gilligan, eds., Hart Publishing 2013)

\section{C) ${ }_{\text {COPYRIGHT }}^{N}$}

This Book is brought to you for free and open access by the Faculty Scholarship at Digital Commons @ University at Buffalo School of Law. It has been accepted for inclusion in Contributions to Books by an authorized administrator of Digital Commons @ University at Buffalo School of Law. For more information, please contact lawscholar@buffalo.edu. 


\title{
The Culture of Financial Institutions; the Institution of Political Economy
}

\author{
David A. Westbrook ${ }^{1}$
}

An expert's questions tend to be bounded by the expert's claim to special knowledge, i.e., expertise, and usually institutional accreditation. So it is unsurprising that when experts who think about the regulation of financial institutions are asked to think about "culture," the issue tends to be framed in their terms (what we know, or at least think we learned in graduate school or in the course of our professional careers). For example, how should regulators confront the culture within a financial institution so that the institution performs in accordance with societal norms, even when the law is unclear? This is a good question (the answer is seven), and as Justin O'Brien's and George Gilligan's excellent "Introduction" to this book makes clear, variations on the question have been heard in recent years across the financial world.

\footnotetext{
${ }^{1}$ Director of Global Strategic Initiatives, Floyd H. \& Hilda L. Hurst Faculty Scholar and Professor of Law, SUNY Buffalo Law School, State University of New York, and author Out of Crisis: Rethinking OuR FinANCIAl Markets, Paradigm Press (2009). The thoughts expressed here were first aired as a keynote for a conference given by the law firm of Allens and the University of New South Wales Centre for Law, Markets and Regulation, "Regulating Culture: Compliance, Risk Management and Accountability in the Aftermath of LIBOR," Sydney, October 26, 2012. I thank the participants for many thoughtful comments. I also thank Justin O'Brian for the invitation to speak, and Jack Schlegel and Douglas Holmes for good reads on short notice. Sean O'Brien provided excellent, and speedy, research help, for which I am grateful. That talk was published, in slightly more polished form, as David A. Westbrook, 'Neofeudalism, Paraethnography and the Custodial Regulation of Financial Institutions,' (forthcoming) JASSA: The Finisia Journal of Applied Finance. Any failings are my responsibility.
} 
David A. Westbrook

Culture of Financial Institutions; Institution of Political Economy

February 18, 2013

As with all ordinary science, much is assumed, as the Introduction also demonstrates. $^{2}$ The model question posed above assumes that we know what financial industries are, and what purposes their regulation serves. Not so long ago, for example, it seemed pretty clear what a bank is, and what the central bank's responsibilities toward such institutions are. This is no longer the case; we now speak not only of shadow banking, but the central bank as dealer of last resort, ${ }^{3}$ and we observe a pronounced unwillingness to follow Baghehot's advice and let insolvent banks fail. ${ }^{4}$ Nor can it be said that we are clear on just what "societal norms" financial institutions are to serve. Sticking with central banking (and by extension, the banking industry in operation) do we think that monetary policy ought to be conducted in accordance with real economic, as opposed to monetary, goals? ${ }^{5}$ For another set of examples, it is easy enough (tautological) to say that fraud is bad, but when we get down to brass tacks -- what disclosure is required under what circumstances, or else the transaction be deemed fraudulent, with financial and even criminal consequences? -- little agreement exists.

To large extent such mindlessness must be forgiven under the flag of Neurath's boat, which must be rebuilt even while it is at sea. ${ }^{6}$ We cannot pay attention to everything at once, and if we seek to address something as nebulous as "culture" in financial regulation, assumptions are going to have to be made. But it should also be acknowledged that our assumptions also may be convenient, or otherwise intellectually dubious. So before we stride off into the rough of financial

\footnotetext{
2 See generally Thomas Kuhn, The Structure of Scientific Revolutions (Chicago, University of Chicago Press, 1996).

3 See Perry Mehrling, The New Lombard Street: How the Fed Became the Dealer of Last Resort (Princeton, Princeton University Press, 2011).

4 Walter Bagehot, Lombard Street: A Description of the Money Market, (London, Henry S. King and Co., 1873) 101-03.

${ }^{5}$ See Charles Goodhart, Central Banks Walk Inflation's Razor Edge, available at http://www.ft.com/cms/s/0/744e4a96-661c-11e2-b967-00144feab49a.html . 6 Otto Neurath, Logical Positivism (Glencoe, Illinois, The Free Press, 1959) 201. The image was later taken up by the Harvard philosopher W.V.O Quine. See W.V.O Quine, Word and Object (Cambridge, Massachusetts, MIT Press, 1960) 3-4. My thanks to Vitor Gaspar.
} 
David A. Westbrook

Culture of Financial Institutions; Institution of Political Economy

February 18, 2013

institution regulation, and what has or has not been learned from the global financial crisis, and what "culture" might mean, at least for the purposes of preventing or at least containing the fire next time, it is worth pausing to reflect on the fact that financial culture is not only, or even most importantly, the culture within financial industries, including of course their customers and regulators. That is, the most important part of financial culture may have very little to do with that on which we, as experts of one sort or another, are authorized to speak. "I'm sorry about the cancer, ma'am, but I'm a podiatrist."

Financial culture also is the product of financial industries; it is the heart of contemporary political economy, what I have elsewhere called the City of Gold. ${ }^{7}$ The GFC matters in a way that, for example, the Silicon Valley bubble did not, not merely because of the former's scale, but because the mismanagement of financial institutions led to the disruption of so many human relationships, most obviously employment relationships. Unemployment -- or lack of employment opportunities - blights a generation. Unemployment correlates with suicide, divorce, and addiction rates. ${ }^{8}$ With massive unemployment (or worse, little employment prospects for the young, energetic, and sometimes violent) we may see a loss of faith in social institutions, a rise in ethnic animosity and virulent nationalism, an anarchist moment. "The best lack all conviction, while the worst/ Are full of passionate intensity," as Yeats has it. ${ }^{9}$ This year, 2013, does not appear to be 1913, nor even 1933, though the situation in Southern Europe remains particularly dismaying. But to say that history teaches that things can be worse is a pathetic

7 See David A. Westbrook, City of Gold: An Apology for Global Capitalism in a Time of Discontent (New York, Routledge, 2004).

8 See Dean Baker \& Kevin Hassett, 'The Human Disaster of Unemployment,' (May 12, 2012) The New York Times, available at http://www.nytimes.com/2012/05/13/opinion/sunday/the-human-disaster-ofunemployment.html?pagewanted=all; Liana Sayer, Paul England, Paul Allison \& Nicole Kangas, 'She Left He Left: How Unemployment and Satisfaction Affect Women's and Men's Decisions to Leave Marriage (May, 2011) 6 American Journal of Sociology 116, 1982-2018; Dieter Henkel, 'Unemployment and Substance Use: A Review of the Literature' (2011) 1 Current Drug Reviews 4, 4-11. ${ }^{9}$ William Butler Yeats, The Second Coming (1921). 
David A. Westbrook

Culture of Financial Institutions; Institution of Political Economy

February 18, 2013

excuse. Members of the financial community (or at least its talking heads) tend to be all too blithe about recent colossal failures, and the harm that has been inflicted not only on "the little people," but also on the structures that sustain the lives of the privileged.

Understanding financial culture, and the failings of the global financial crisis, in social terms does more than to remind us of the human significance of events, significance that is perhaps easy to forget in technical discourses on institutional regulation. Indeed part of the point of this or any other expert discourse (consider here medicine, or the military) is to be able to discuss fraught questions, such as cancers, bombs, or indeed insolvencies, as if they were merely objective. And in recent years the discipline of economics has struggled to define itself in scientific terms, understood to be concerned with objects, and thus in some sense outside of culture and by extension politics. So, from an economic perspective, one may speak of, for familiar examples, the independence of central banking, or a "technical" government, or make the claim that while it is clear what reforms need to be made, the problems are political.

But from the more traditional and perhaps defensible perspective of political economy, finance is social in the structural sense used by sociologists and anthropologists. Our financial institutions are absolutely central to the way we as people conduct ourselves and understand our lives. This may be most obvious in the United States, where so many social goods, including much education, health care, and retirement, are provided through institutions directly dependent on portfolio investment. But as the European debt crisis makes clear, in countries where social obligations are met by the state, governments are quite dependent on healthy financial markets, in turn dependent on healthy "private" (!) financial institutions. Other examples abound. We securitize fixed assets. We pay for daily operations through credit arrangements, both as individuals (credit cards) and businesses (commercial lending and paper). As both individuals and especially institutions, we are comfortable with leverage, exchange rate risk, and all sorts of other dangers, in large part because we have developed derivative markets intended 
David A. Westbrook

Culture of Financial Institutions; Institution of Political Economy

February 18, 2013

to hedge our risks. One could go on, but in short, we have capitalized our worlds -this is what it means to have a "social capitalism."10 To put the matter differently: if the GFC represents a colossal failure of finance, it also demonstrates just how successful finance has been in monetizing contemporary economies, so that it seems rather quaint to talk about the distribution of goods and services and the problem of scarcity.

Thus while we still tend to teach finance in entrepreneurial terms (finance is progressive, because it allows people to do what they cannot do out of retained earnings), credit -- sweet liquidity -- is absolutely central to daily operations of leveraged (and interconnected, and vulnerable) governments, institutions and individuals. All of this makes the spectacle of young bucks at Barclays promising one another bottles of champagne in exchange for modest market manipulation ${ }^{11}$ seem like a farce, but symptomatic -- Marie Antoinette dressing up as a shepherd. And this makes financial regulation an essentially custodial, or as is said in the banking context (now including the securities context) ${ }^{12}$ "prudential," enterprise, like the provision of electricity or water.

At this point, the expert debate on the regulation of financial institutions does not seem so harmless. Without being sentimental, at issue is not merely how banks and other financial institutions are to be run, but our political economy, i.e., little questions like whether kids in Spain will ever get a job, or just how many people in the US will be on food stamps. It would be intellectually convenient to say, with Foucault, that our claims to expert knowledge are also assertions of authority, power. ${ }^{13}$ While there is a truth here, this point is easily overdone: bureaucrats want to live comfortably, which requires a modicum of authority, but not power in the

10 David A. Westbrook, 'Dinner Parties During 'Lost Decades': On the Difficulties of Rethinking Financial Markets, Fostering Elite Consensus, and Renewing Political Economy,' Seattle Law Review (September 15, 2012) 29-32, Forthcoming. 11 Report From The Treasury Committee of Parliament, Fixing LIBOR: Some Preliminary Findings (August 18, 2012).

12 See Mehrling, The New Lombard Street (2011).

13 Michael Foucault, Discipline and Punish (New York, Pantheon, 1977) 184. 
David A. Westbrook

Culture of Financial Institutions; Institution of Political Economy

February 18, 2013

sheer rushing sense of being Alexander. Few bureaucrats, including bankers, seek

to conquer India or even be the big swinging dicks legend has it stalk Wall Street.14

More modestly, in bureaucratic fashion, we might ask, if social capitalism is the

"culture" of which financial institutions are the mainspring, then what sort of social

capitalism may be hoped? That is, if we ask about the culture of our political

economy, then what does that teach us about the culture we seek to foster in our

financial institutions?

Regulators have turned to "culture" in frustration. ${ }^{15}$ Through the GFC and now again with the LIBOR scandal, we observe market participants who simply do not abide by the spirit of the rules. 16 They are, in a word, bad sports. So how do we as a society -- and in particular regulators, charged with refereeing the markets -get financiers to be good sports? Or as a recent conference given by the law firm of Allens and the University of New South Wales Center on Law, Markets and Regulation phrased it, how do we regulate culture? ${ }^{17}$

In policy discourse, culture is commonly approached in two basic ways, both centered on the notion of assessing the significance of an action vis-a-vis a social frame of reference, the "culture."

Lawyers tend to think of culture on the model of law, conceived of as a rule. So, cultures establish rules. Big general rules are expressed as laws (statutes, judicial decisions, constitutions); technical administrative rules are usually called

\footnotetext{
14 See e.g., Tom Wolfe, The Bonfire of the Vanities (New York, Picador, 1987).

15 See 'Regarding Culture: Compliance, Risk Management and Accountability in the Aftermath of LIBOR,' (Oct. 26, 2012) The Centre for Law, Markets, and Regulation. 16 See Rosa M. Abrantes-Metz, Michael Kraten, Albert D. Metz, and Gim S. Seow, 'LIBOR Manipulation?' (2011) 36 JoURNAL OF BANKING \& FINANCE 1, 136-150; see also François Laurens, 'UK Banking Regulatory and Market Framework: Post-Crisis Reform,' (July 2012) Swiss Management Centre (SMC) University. 17 See Westbrook, Neofeudalism, Paraethnography, and the Custodial Regulation of Financial Institutions, supra note 1.
} 
David A. Westbrook

Culture of Financial Institutions; Institution of Political Economy

February 18, 2013

regulations; the softest and most "cultural" rules are deemed norms, e.g., best practices, which may be important even in the absence of an official sanction. In this view, law is often understood to bound otherwise free behavior, much as a fence bounds movement. The law determines a "line," it is often said, which is not to be crossed. As with borders, the metes and bounds of real estate and mining claims, the claims of patents -- the imaginary of the "line" is ubiquitous in the law -- the lines of financial regulation are themselves invisible. They are products of statute, regulation, and best guesses as to, as Holmes wrote, "what the judge will do in fact" - and as such are subject to professional divination (funny how Holmes's emphasis on "fact" so quickly requires "divination" -- faith and a gift). ${ }^{18}$ In consequence, entrepreneurs often seek legal advice, and lawyers themselves may turn to regulators, e.g., by seeking a no-action letter at the SEC, for some sense of where the law's lines are. If, however, a transaction is deemed to be within the fence, then the actor is free to take the action. This imaginary is familiar, useful, indeed inescapable -- but it must be recognized as only one way of imagining the law.

Economists tend to begin with rational actors who are incessantly attempting to better their situations. When contemplating an action, such actors evaluate the benefits (incentives) and harms (disincentives) they are likely to receive from taking, or not taking, the action. Many incentives are determined by other people. For example, a bank might not want to be known to take unreasonable risks, because a reputation for recklessness might dissuade people from depositing money or otherwise investing in the bank. In extreme cases, a bank could lose its license. So, for the bank, the immediate expected profit (return on investment) must be balanced against somewhat more nebulous reputational risk if the investment goes bad, and people find out.

If lawyers unsurprisingly imagine culture to be like law, and imagine law as drawing lines that constrain otherwise free behavior, economist unsurprisingly imagine culture as a market, presenting opportunities and imposing costs on

18 See Oliver Wendell Holmes Jr., 'The Path of the Law' (1897) 10 Harvard Law Review 457. 
David A. Westbrook

Culture of Financial Institutions; Institution of Political Economy

February 18, 2013

rational actors. Both approaches fundamentally externalize culture as something to be confronted by actors, as outside the actors, like weather. Neither approach understands culture to constitute market actors, or more especially the institutions that empower people to operate at all. (One cannot do a merger in the state of nature.) To be blunt, financial policy discourse tends to have a very shallow understanding of culture. There are exceptions, of course, and not to be unkind, but people with profound understandings of the significance of things tend to occupy themselves with endeavors other than the manipulation of money. And it was precisely the shallow understanding of financial culture regnant in financial discourse -- culture reduced to the black letter rules of endless yet ineffectual financial regulation, and the undue faith that self-interest, including reputational cost, would serve to discipline risk-taking -- that, we were told by Greenspan and others, would ensure the soundness of our financial markets. ${ }^{19}$ Suffice it to say, such weak thinking has been of little help in recent years. Clearly, if financial culture is to be a part of the solution, then a more serious understanding of financial culture is required.

So how might we begin to think about financial culture? We might begin by thinking not about "culture" in the abstract, but as found in specific situations. Indeed, not only does "culture" resist final definition, as O'Brien and Gilligan note in the Introduction, but much anthropology of the contemporary does not even try. ${ }^{20}$ None of the cultural anthropologists with whom I speak make any attempt to define "culture" objectively and externally. Instead, one attempts to understand this or that "present situation"21 (other frequently heard words are "assemblage" and "constellation") -- my friend Doug Holmes' forthcoming work on central bankers is

${ }^{19}$ See Chairman Allan Greenspan, Remarks before the 31st Annual Conference on Bank Structure and Competition (May 11, 1995).

20 O'Brien \& Gilligan, Introduction at.

21 David A. Westbrook, Navigators of the Contemporary, Why Ethnography Matters (The University of Chicago Press, Chicago, 2008) 27-28. 
David A. Westbrook

Culture of Financial Institutions; Institution of Political Economy

February 18, 2013

exemplary. ${ }^{22}$ In this view, culture is a placeholder for a web of understandings in which both anthropologists and their interlocutors are implicated. So for example, we might look at actors surrounding LIBOR: the various reporting banks (including investment bankers, traders, and directors, to say nothing of shareholders, depositors and other investors, as well as counterparties); the British Bankers Association, Thompson Reuters, the regulators broadly construed, including not just the Financial Services Authority (FSA) and the Bank of England, but ultimately Parliament itself; and perhaps most importantly, those who use LIBOR, and those who study it, including the ethnographer herself, with her capacities, limitations, and interests.

To put it differently, LIBOR may be understood not as an objective fact (that is self-evidently naive, or should be by now), but as a collective narrative about the expected cost of various forms of capital. Contemporary economies evidently need a collective narrative about the future cost of capital, more prosaically known as a benchmark. $^{23}$ A serious ethnographic inquiry into how such a tale is told could be useful. Such an inquiry might even help legislators in their task of encouraging more reliable tellings.

As suggested above, however, we also could begin our inquiry into financial culture from the outside, rather than the inside, of financial institutions. We might begin by thinking about financial culture in terms of their artifacts, the products of financial institutions that we use every day, and that shape the way we live. In other words, we might think about financial culture in terms of political economy writ large, as that which financial institutions institute, make: our commercial society.

So how does finance work in the social world? For purposes of discussion, entertain the following proposition: the Occupy Wall Street movement considered (perhaps generously) as argument, was descriptively correct and normatively

22 See Douglas R. Holmes, Economy of Words: Communicative imperatives in Central Banks (Chicago, University of Chicago Press, 2013).

${ }^{23}$ See Martin Wheatley, 'The Wheatley Review of LIBROR,' (2012) The Financial Services Authority. 
David A. Westbrook

Culture of Financial Institutions; Institution of Political Economy

February 18, 2013

incorrect. That is, Occupy Wall Street was right to complain about the $1 \%$ (or better, less); substantial material inequality in fact inheres in contemporary market societies. Consider further the possibility that, despite regnant ideologies of autonomy and equality, our fundamental social structures cannot plausibly be discussed in those terms. To be blunt, Occupy Wall Street was normatively wrong to believe that our society -- that any financial society, including proudly egalitarian Nordic ones -- is fundamentally about equality and autonomy.

Progress, as Henry Sumner Maine famously wrote, consisted in the historical movement from societies in which order was defined by status or birth, to societies in which order was defined by contract. ${ }^{24}$ This is as succinct a definition of liberal modernity as one might wish, and its connections to commercial ideology are both visible to this day and well documented. 25 But suppose that finance does not work that way. Suppose that in moving from an economy of goods and services to an economy of money, and from the antithesis of capital and labor familiar since Marx to social capitalism, we have also moved from contract to status as the foundation of social order. Suppose we are neo-feudal, and have not yet awoken to our lives?

A full account, much less defense, of this idea would require a book that I may not write. Among other things, I find the idea unappealing, and the days are short. So the rest of this essay may be considered maliciously suggestive, an ideological ghost story, at the very least a provocation. But if our society is inherently unequal, and that inequality is realized and enforced through financial institutions, surely the regulation of financial institutions ought to reflect that reality? More broadly, how might we think about political economy writ large after republican pieties have been washed away in a sea of liquidity, or, to put it more bluntly and in European terms, after austerity has made it clear what matters?

In hesitantly entertaining such politically incorrect (for heirs of the French Revolution, blasphemous) thoughts, let us begin innocently enough, with the

24 Henry Summer Maine, Ancient Law (J.M Dent \& Sons, 1861) 170.

25 Guyora Binder, 'Legal Metaphors for Self in 20th Century Social Thought,' in Looking Back at Law’s Century (Cornell University Press, New York, 2002). 
David A. Westbrook

Culture of Financial Institutions; Institution of Political Economy

February 18, 2013

example of travel. One sets out armed with a piece of plastic and sometimes a little book (for Americans, the book is blue). The traveler exhibits her tokens to people, generally "agents" of governments or corporations. If the tokens are found valid, the traveller is given airplane rides, hotel rooms, refreshments, and so forth. The traveler retains the plastic and the book, indeed, need not give anybody anything. Instead of actual exchange, various accounts on various computers are changed, i.e., by "payment" we usually mean a communication and a promise to account. Thus travel and for that matter economic activities generally take place in "economies of money."26 Virtually all of what is "exchanged" does not exist in any material sense. "Exchange" has itself become a metaphor for essentially legal communication about the terms of financial instruments, promises to alter numbers which, like sports statistics, express relative standing. All that is solid melts into air, as it were. ${ }^{27}$

One cannot think of communication (one cannot speak) outside of a culture. Financial culture is the water in which we all swim, regulators and regulated and just plain folks. Finance itself is an expression and constitutive of culture; payment (contract, property, and so forth) is always already cultural. Thus the recent discovery of "culture" in financial discourse-- as an afterthought, what to do when the rules fail to keep up with developments in the market -- is wrongheaded. In the same vein, the imaginary of the lawyers and economists, for whom culture is understood is something to be confronted by actors, as rule or incentive, is misleading. Culture was always the question, and culture was always also internal to the individuals, institutions, modes of interaction that constitute financial markets.

If culture was always the question, then why has culture come to the fore just now? What has changed in recent years? For a long time, before the GFC, the culture of financial elites was both workable and tacit, went without saying (comme

26 David A. Westbrook, Problematique in Rethinking Financial Markets, The World Economics Association, http://rfconference2012.worldeconomicsassociation.org/problematique/. 27 Karl Marx \& Friedrich Engels, The Communist Manifesto (Joseph Katz ed., Samuel Moore trans.) (1848) 32. 
David A. Westbrook

Culture of Financial Institutions; Institution of Political Economy

February 18, 2013

il faut), and so "culture" was not something that required worrying. Business communities, like all communities, have their virtues and of course their vices. It is important to remember, however, that such arrangements are not stable over time (virtues and vices have histories). So, for example, by the 1930s, New York had been a financial center for generations; surely business could not have been done for so long and on such scale if everyone were a cheat and there were no trust. But the Peccora Commission, or in our time, Eliot Spitzer, were not wrong in their aspirations to clean up Wall Street, asserting that norms had faded and needed to be enforced. ${ }^{28}$ Not even crime is constant. So with regard to British banking, as with regard to investment banking on Wall Street, knowledgeable commentators report their sense that social norms have frayed, that business is not what it used to be. (Corporate lawyers universally do so.) That is, when a commercial culture is working, and especially when money is being made, the question of culture fades into the background. When a community's norms lead it to harm itself, culture comes into question.

So it is because these are hard times -- because our financial thinking or at least policy failed to prevent disaster -- that we must think anew about financial culture. We must reconsider whether we still believe what we long thought we know about financial culture, viz., is it really sensible to think about finance in terms of the trade of scarce resources, i.e., the exchange of goods, among equals? To shift examples slightly, assume that you "order" dinner, or better still, "command" it in French, and your credit card is accepted, that is, the waiter (or "server") and the kitchen obey your wishes. The restaurant and its staff accept that you are the sort of person to whom dinner should be brought. Unless you leave a tip in cash on the table, you do not actually pay for the meal. You send (or sign) a message authorizing your institutions to credit their institutions. Various back offices handle

${ }^{28}$ See e.g., The United States Committee On Banking and Currency, The Pecora Report: The 1934 Report On the Practices of Stock Exchanges From the "Pecora Commission," available at www.archives.gov; see also Adi Ignatius, 'Eliot Spitzer: Wall Street's Top Cop,' (2002) Time Magazine. 
David A. Westbrook

Culture of Financial Institutions; Institution of Political Economy

February 18, 2013

looking out for the restaurant, which looks after its suppliers, its staff, and so forth. From this perspective the credit card establishes the diner's social standing. Credit transactions are rather feudal, in the fairly literal sense of a web of obligations and obedience built upon trust.

There are, of course, other accounts to give of what it means to order dinner. Those on the left would like to maintain that people get things, or should get things, because they have done some work. That would be nice, but let me be honest: I do not work much, and therefore do not assume that wealth is the artifact of labor. More to the point, I do not work for the waiter, and what work I have done, he does not know. All he knows is I have plastic, and that is more than enough. Or, to turn the problem around, feudal lords "worked" too: they fought their kings wars, struggled with rivals, ran manors, and sired heirs. But it would be foolish to say that they were obeyed in exchange for their labors.

Those on the right sometimes maintain that capital markets, great engines of progress and security, require investors. Even though investors do not work, they bear risk, for which they should be paid. As a professor of finance, I teach this story, but again, I really do not risk much. I have tenure, and I hope I am not being let onto a plane to bear risk. In short, neither the ideology of the left nor the ideology of the right does a very good job of articulating what is happening in an ordinary financial transaction: on the basis of messages -- in this case, swiping credit cards -- agents are authorized, or not authorized to act.

As already suggested, this does not sit well with the liberal mind. Conventionally, we imagine transactions as exchanges among contracting parties who are legally presumed to be equals. That is, we see economic activity as the expression of liberty, choice: one chooses to buy or sell. We speak of "free markets" instead of "command economies" much less "neofeudal obligation." We conceive of liberty in opposition to status. So the wife, child or slave under the Roman law (patria potestas) are unfree -- their social position is determined not by their choice, but by action of law, generally referring to the circumstances of birth or battle. That is, liberal political economy has often defined itself in opposition to other ways of 
David A. Westbrook

Culture of Financial Institutions; Institution of Political Economy

February 18, 2013

social ordering. Maine himself was a scholar of Roman law, and intimately familiar with the Indian caste system. But to say that 19th century England or the 21st century US is unlike the Rome of the 12 Tables does not mean that our own selfunderstanding is sufficiently deep, that we have our ideology right enough. The fact that a world of difference exists between being a "server" today and chattel slavery in the US in the early 19th century does not mean we should understand restaurant service in terms of autonomous exchange rather than, literally, service.

As noted, in economies of money, we see webs of obligation without direct exchange. We see service, indeed, obedience, even if not the right to physical coercion or outright alienation, as with chattel slavery. In "The Theory of the Firm," Ronald Coase was disturbed by the fact that so much economic activity was governed by hierarchies of command rather than by bargain, a price mechanism. ${ }^{29}$ He argued that a system of contractual subservience saved transaction costs. Perhaps, but this led Coase to the uneasy recognition that any economic system -including slavery -- might be justified on the basis of efficiency demonstrated by its existence. ${ }^{30}$ Coase took refuge in, of all things, the law. Agency law, in twentieth century Anglo-American systems, simply did not allow employment agreements for indentured servitude, and slavery was illegal, so its practice could not be taken as evidence of a saving of transaction costs. ${ }^{31}$ But if the question is what should the law be, i.e., how should we begin thinking about the regulation of financial institutions, and in particular, their hierarchical exercises of power, "the law" is hardly an answer. What law?

Much more may be said about the use of "transaction costs" to rescue the economic imaginary of autonomous and presumptively equal contracting parties, but more old fashioned and honest words are "privilege," "status," and even "class,"

${ }^{29}$ See R. H. Coase, 'The Nature of the Firm,' (Nov., 1937) 4 Economica, New Series 16, 386-405.

30 See ibid. at 403-04.

31 David A. Westbrook, 'A Shallow Harbor and a Cold Horizon: The Deceptive Promise of Modern Agency Law for the Theory of the Firm,' (2012) 35 Seattle U. L. Rev. 1369, 1373-75. 
David A. Westbrook

Culture of Financial Institutions; Institution of Political Economy

February 18, 2013

understood as a relation to authoritative institutions and especially the social capital they command. It should go without saying that corporations, including banks, are -- as the church and the military have always been -- such authoritative institutions.

Currently polite words for economic status are title, meaning institutional affiliation, and brand. So an individual may be invited to teach in a university, or run a large bank, and exercise the authority of that office, because that individual has achieved a certain reputation among those with the power to appoint, what the Middle Ages meant by the word "invest." There is an amusing moment, at policy and academic conferences, when speakers publicly proclaim that they are not speaking in their institutional capacity. True enough, of course, in the sense that the presenter is not formally authorized to speak for the institution understood as a corporate body. But the vast majority of speakers must be legitimated through a chain of institutional affiliations, or they would not be asked to speak at all. Nobody besides perhaps great artists speaks purely on their own authority. Titles matter, hence nametags.

A business attracts custom -- depositors and other investors in a bank -based on a differentiated reputation, secured by the sorts of intellectual property that make up a brand. But investors generally do not "know" what "their" banks do. As Jamie Dimon will admit, even bankers are pretty hazy on what their institutions are doing. ${ }^{32}$ Investment is usually highly social, based on reputation and commonly held (hence publicly defensible) belief, and hence the need for credit rating agencies.

From this perspective, handing over a credit card is like showing a letter from the king, or wearing a uniform that displays an officer's rank. The credit card establishes a position vis-a-vis a chain of financial institutions, and by extension, the governments that attempt to back them up, not always successfully. None of this is very democratic, and in that sense not very modern, and therefore difficult to think,

32 See U.S. Senate Committee on Banking, Housing, and Urban Affairs, Hearing: A Breakdown in Risk Management: What Went Wrong at JPMorgan Chase?

(Wednesday, June 13, 2012) Testimony of James Dimon. 
David A. Westbrook

Culture of Financial Institutions; Institution of Political Economy

February 18, 2013

but so it goes. Unsurprisingly, financial discourse typically treats payment in terms of an Arcadian quid pro quo, in spite of the fact that financial activities (collectively, culture) consists largely of communications about relative social standing defined in terms of accounting. And, after Enron and Worldcom, the implosion of various intensively managed financial institutions during the GFC, the Greek scandal, and now LIBOR, accounting seems to be a rather dubious enterprise.

At this point in the discussion we have sketched a political economy (social capitalism) founded primarily on economies of money (the exchange of tokens, rather than goods or services) in which "trade" consists largely of communications about relative social standing defined in terms of a rather dubious system of accounting. ${ }^{33}$ In this context, how might we think about regulating financial culture?

At least four differences between the regulatory demands of the social capitalism we in fact have and the orthodoxies of contemporary regulatory discourse (what both regulators and regulated say) are salient.

First, insofar as economic activity consists of communications that affect relative standing ("positions") among authoritative institutions, the public/private distinction is largely effaced. From the bottom up: webs of speech form the public sphere. The fact that speech is transactional does not somehow make it private. (The agora is a public space.) From the top down, all of the actors are licensed, regulated, and generally insured by the government. To quip, all finance is more or

33 It is worth noting in passing that the supply of tokens is in principle infinite -limited by the willingness to participate (promise, bet, extend credit). But if supply is indefinitely large, is indeed positively associated with demand, then distribution under conditions of scarcity are hardly what financial markets, at least, are doing. This essay therefore could have focused not on the absence of exchange, but the political character of both supply and demand, and by extension, the social (cultural) qualities of price, none of which can easily be squared with liberal theology. As financial markets, especially derivative markets, become more important to how society operates, political economy should be revised accordingly. 
David A. Westbrook

Culture of Financial Institutions; Institution of Political Economy

February 18, 2013

less public, a lesson from the recent wave of bailouts, and once again being demonstrated in Europe. ${ }^{34}$

Second, almost all actors at issue in finance are officials, whose authorities and obligations are defined by law. Banks are institutions authorized to conduct certain kinds of intermediation. Bankers act not in their own capacity, but as officers of the bank. The legal capacity to dispose of assets depends on institutional status and authority, almost never on personal ownership -- even in the case of socalled proprietary trading. Shareholders simply have no legal power to dispose of corporate assets. Thus the imagination that suffuses financial policy discourse, of the sheriff attempting to constrain yeoman traders, is silly. Financial policy asks, or should ask, after the proper relationships among different sorts of bureaucrats, whose powers are legally defined, whose collective actions allocate assets. The fact that an economy is neither a command economy nor even socialistic (the state does not have substantial ownership of key enterprises), does not mean that markets are not institutionally and legally comprised, and therefore only understood in social terms.

Third, and by extension from the first two points, the regulator and the object of regulation need to be understood in terms of one another, reciprocally rather than antagonistically. Here again the metaphor of sports is instructive. The referee does not exist without the game. Conversely, games cannot be won without a set of conventions to determine the bounds of the field, what counts as a point, and the like. To understand rules -- and regulators, and ultimately law -- as essentially external to marketplace activity is a common error, but an error nonetheless. It is legal instruments that are being traded, all the way down.

Fourth, regulators and policy makers and even academics are conceptually "within" the culture they seek to regulate. To some extent, this is a matter of biography -- one must know a lot of finance even to follow the conversation.

${ }^{34}$ Incidentally, it is not entirely clear what is meant, in the LIBOR context, by 'unsecured' lending. Who needs collateral if obligations are backed by the taxing power of the state? 
David A. Westbrook

Culture of Financial Institutions; Institution of Political Economy

February 18, 2013

Cultural bias is also a matter of interest. The Wheatley Report is quite candid about the government's wish to preserve the preeminence of London as a financial center. ${ }^{35}$ More profoundly, financial market participants have difficulty thinking about finance in ways other than "like what we've done, only somewhat better." And, as noted above, financiers, like practitioners of most any art, are good at thinking about how to do what it is they do -- they are far less good at thinking about what it means. ${ }^{36}$

To sketch the image of financial culture that is emerging: contemporary social capitalism uses more or less competitive markets, operated and overseen by corporate and governmental officials (bureaucrats) in reciprocal relationships, within shared webs of understanding, to determine the flow of goods, services, and most importantly the financial assets (social capital) that largely determine the power of institutions, including governments, the provision of social services, and much of the status of individuals (who is rich). If this -- rather than some sort of fence, within which private actors legally deemed to be equal seek personal gain through trade, perhaps in the faith that the invisible hand will direct the sum of their actions to the common weal -- is a plausible description of our capitalism, then what might be said about financial culture? Financial culture is far more social, bureaucratic, hierarchical, and intellectually conservative than is commonly admitted in, for example, the pages of the Wall Street Journal. (One recalls Schumpeter's thoughts about the end of capitalism, i.e., the entrepreneur giving way to the manager. ${ }^{37}$ )

What might be said about regulation in such a society? The general impulse of the law is conservative. In ordinary times, the king wishes to see good order in his kingdom, whenever and wherever he might reign. Even in times of revolution, the authority of the law is almost always understood as prior -- the ancien regime

35 See Wheatley, The Wheatley Review of LIBOR.

${ }^{36}$ A point that runs back at least to Plato.

37 See generally Joseph Schumpeter, Capitalism, Socialism, and Democracy (George Allen \& Unwin Publishers 1943). 
David A. Westbrook

Culture of Financial Institutions; Institution of Political Economy

February 18, 2013

has strayed from the true law, and therefore must be overthrown, so that society may return to the path of righteousness (hence "revolution," a wheel returning to whence it began). ${ }^{38}$ So we may assume that the financial regulation required by social capitalism will be, or should be, custodial in character.

As noted above, the social order has largely been capitalized -- we rely on portfolio management to ensure the operation of our governments, our payment systems, the way institutions and individuals operate daily. We rely on endowments to provide social services, ranging from education to health care to retirement. In such a deeply capitalistic society, financial markets are essentially like utilities or weapons systems: disruption of operations cannot be tolerated for any length of time. From this perspective, the purpose of financial regulation is to ensure smooth functioning, even at the cost of liquidity and capital formation, of financial markets in which positions are taken, and by extension, portfolios are constructed. In short, the shift from entrepreneurial capitalism to social capitalism implies a corresponding shift, admittedly not yet taken, from permissive regulation to custodial regulation.

How might one begin to think about custodial regulation? While it is difficult to think about the context of one's own thought, it is not quite impossible. Much contemporary anthropology is marked by the acknowledgment that it fundamentally is "reflexive" rather than objective -- the account of a culture is always also the account of the writer of the culture. Hence the transformation of anthropology in the 80's has been called "writing culture." 39 The difficulty in the anthropological enterprise is acknowledging the self-referential character of the inquiry, and proceeding nonetheless. ${ }^{40}$ Something similar might be said -- is being said -- about the need for financial market regulators to think about the culture that

\footnotetext{
38 Harold J. Berman, Law and Revolution: The Formation of Western Legal Tradition (Harvard University Press, Massachusetts, 1983) 20.

39 See generally George Marcus \& James Clifford, Writing Culture: The Poetics and Politics of Ethnography (University of California Press, California, 1986).

40 As another aside, economics and so finance has not yet really taken the turn to interpretation that marks the rest of the social sciences and also the humanities.
} 
David A. Westbrook

Culture of Financial Institutions; Institution of Political Economy

February 18, 2013

they are trying to regulate, yet which forms their own understanding of what it is that they regulate.

LIBOR itself is reflexive. The respondents are asked at what rate would your important bank be able to borrow a reasonable sum in a given currency for a specific tenor at 11:00 am? ${ }^{41}$ In constructing LIBOR, the BBA, through Thompson Reuters, asks bankers for their view of their place in the world, asks them to enact Keynes's beauty pageant on themselves. ${ }^{42}$ In speculating on the price at which a bank would be able to borrow a reasonable sum, the LIBOR respondent is forced to ask himself how (un)desirable is my credit in the context of this currency market?

My friends the anthropologists Doug Holmes and George Marcus have termed such insider/outsider views of a present situation, like participating in a LIBOR survey, "paraethnographic."43 Actors in complex contexts like large banks must articulate their own culture, and their standing within it, to themselves as a condition of their functioning in the culture, doing their jobs. Although global finance is an impossibly complex context, those who would act within it must in fact imagine it somehow, tell themselves some story about it, in order to be able to navigate -- much as ancient sailors had to have some picture, however incomplete, of their seas. Rephrased, participants in complex contemporary sites stand in much

41 See Wheatley at 22.

42 See John Maynard Keynes, The General Theory of Employment, Interest and Money (Harcourt, Florida, 1953) 156.

43 See Douglas R. Holmes and George E. Marcus, Collaborative imperatives: $A$ Manifesto, of sorts, for the re-imagination of the classic scene of fieldwork encounter, in Collaborators Collaborating: Counterparts in Anthropological Knowledge and International Research Relations, (Monica Konrad ed., 2012) 126-43; Douglas R. Holmes \& George E. Marcus, Cultures of Expertise and the Management of Globalization: Toward the Re-functioning of Ethnography, in Global Assemblages: Technology, Politics, and Ethics as Anthropological Problems, (Aihwa Ong \& Stephen J. Collier eds., 2005) 235-52; Douglas R. Holmes \& George E. Marcus, Fast Capitalism: Para-Ethnography and the Rise of the Symbolic Analyst, in Frontiers of Capital, Ethnographic Reflections on the New Economy, (Melissa S. Fisher \& Greg Downey eds., 2006) 33-57; Douglas R. Holmes \& George E. Marcus, 'Collaboration Today and the Re-Imagination of the Classic Scene of Fieldwork Encounter,' (2008) 1 Collaborative Anthropologies 136, 170. 
David A. Westbrook

Culture of Financial Institutions; Institution of Political Economy

February 18, 2013

the same relationship to their own cultures as traditional anthropologists stood in relation to native cultures.

Not only do actors describe their contexts to themselves, in so doing, they help constitute the context. For present example, LIBOR is traded upon. The beauty contest establishes standards of beauty. Nor is LIBOR the only place where we observe financial conversation operating to create the conditions under which finance is done. Consider inflation targeting: central banks announce not only their objectives, but the means by which they hope those objectives will be achieved, in a self-conscious effort to have those objectives priced in and traded upon, in a communicative circle. ${ }^{44}$

A paraethnographic perspective, i.e., a conversational style of anthropology, could provide some grasp on contemporary contexts, and especially on how complicated bureaucracies like banking generate social, economic, and inevitably political realities. ${ }^{45}$ The opportunity for anthropologists, and perchance bankers and their regulators, is to make critical use of paraethnographic perspectives to accomplish not the interests of their interlocutors, but their own objectives, whether it be complex evaluation or the maintenance of sound markets. If regulators were to approach their jobs through a paraethnographic understanding of financial institutions, then the regulatory relationship, especially with regard to prudential regulation, would be subtly but pretty profoundly reconfigured.

The Bank of England's Andrew Haldane recently gave a very fine speech at the Federal Reserve's annual meeting in Jackson Hole. ${ }^{46}$ In it, Haldane argued that financial regulation, and specifically the Basel process, had grown far too complex -and that such complexity was counterproductive. So Haldane argued that compliance with norms should rely less on elaborate articulation of rules, and rely

\footnotetext{
44 See Holmes, The Path of Law.

45 See e.g., Westbrook, Navigators of the Contemporary.

46 See Andrew G Haldane, Executive Director, Financial Stability and member of the Financial Policy Committee, Bank of England, address at the Federal Reserve Bank of Kansas City's 36th economic policy symposium, The Changing Policy Landscape (August 12, 2012).
} 
David A. Westbrook

Culture of Financial Institutions; Institution of Political Economy

February 18, 2013

more on the judgment of experienced officials. In terms of the common law

tradition, Haldane argued that it was time for regulators to shift their approach from law toward equity. One might also make an analogy to perennial argument between rule-based and principle-based approaches to accounting. Haldane was not too explicit about what bank regulation would look like under such circumstances, but it seems fair to imagine that there would many discussions in which regulators asked actors to convince them why their practices were safe, and their portfolios sound. Another analogy might be drawn to a start up business, perhaps a technology company, which seeks early stage investment. The onus is on the leaders of the young business to explain to potential investors why theirs is a good idea, worthy of realization. The regulator of an important financial operation should be considered invested, under the motto, "If you fail, I fail."

The argument here is not nearly as abstract as it may appear. To recapitulate: as the GFC has demonstrated, vast numbers of tax dollars may be spent, unemployment may rise, growth falter, and the host of institutions that rely on pools of assets, from family retirement and education funds to sovereign debt, may be shaken. Relationships may fray and individual human possibilities may be diminished. Contemporary societies depend on well functioning financial markets much as they depend on electricity, hence "social capitalism."47 To be blunt, the (orthodox) understanding of financial markets as the bounded interaction of essentially private actors (the understanding with which discussions of culture generally begin) is both intellectually primitive and politically impoverished. Understanding finance in human terms -- social capitalism -- should cause one to understand regulation in explicitly custodial terms, in which bankers and their regulators come to mutually agreed understanding on how to manage assets. Thus the relationship between regulator and regulated could be transformed, from one of

47 See Westbrook, Problematique. 
David A. Westbrook

Culture of Financial Institutions; Institution of Political Economy

February 18, 2013

opposition to mutually reinforcing, and interdependent, participation in the custody of social assets. ${ }^{48}$

A custodial approach to regulation should engender, within regulatory relationships, the sensitivity and tough mindedness traditionally associated with trust obligations. ${ }^{49}$ From this perspective, regulators might think of what happened at Barclays and many of the shenanigans of the last years not just as actions of a few "bad apples," or even as more general expressions of a corrupt institutional culture, but as a kind of personal and professional betrayal, for which the appropriate response is anger. If management deceived key equity investors in a company, would we not expect to see such managers replaced, and in the extreme case, the company merged out of existence? It would have been completely understandable had the radical interventions of 2008 and since resulted in the dissolution of the corporations involved: the discharge of management, the forfeit of equity, and the abolition of the brands. While some banks, especially smaller banks and especially in the US, were resolved, over and over again and in jurisdiction after jurisdiction, banking, which is necessary, was confused with specific banks, which are replaceable. And banks, as Bagehot taught a long time ago, should conduct themselves with the understanding that they are replaceable. ${ }^{50}$ And even if a society does not have the stomach to replace its banks, it should at least have the will to replace its bankers.

From a paraethnographic perspective, however, there is a structural reason to dissolve banks or at least discharge management: if management is no longer trustworthy, then the paraethnographic regulation, founded on trust, is not possible,

48 The elegant exchange of letters between Barclays Chairman Marcus Agius and the FSA's Adair Turner is exactly what I'm NOT talking about. See The Exchange of Letters Between Lord Turner, Chairman of the FSA, and Marcus Agius, Chairman of Barclays, available at http://www.publications.parliament.uk/pa/cm201213/cmselect/cmtreasy/481/4 8111.htm.

${ }^{49}$ See e.g., Meinhard v. Salmon, 249 N.Y. 458 (1928) (A trustee is held to something stricter than the morals of the market place ...).

${ }^{50}$ See Walter Bagehot, Lombard Street. 
David A. Westbrook

Culture of Financial Institutions; Institution of Political Economy

February 18, 2013

and the institution cannot be licensed or backed by the state. Society should replace its bankers with more trustworthy, careful, or at least blameless, mandarins.

Turning to specifics, and the immediate occasion for this essay: what does a custodial understanding of regulation mean for the efforts to "fix" LIBOR? Most proposals for reform, including Wheatley, treat LIBOR as if it were a device like a thermometer that directly measured an aspect of the natural world, and Barclays and others tampered with the instrument, so that it gave an inaccurate reading. But LIBOR doesn't measure anything outside the social context of its formation. As every teacher knows, at the end of the day, performance on a test is always about the test and maybe the class, but only tangentially about the truth. Similarly, LIBOR is a ritual for expressing sentiment about the cost of capital and therefore the relative standing of financial institutions in the present environment. But nothing is measured. LIBOR estimates are provided even in the absence of trades, that is, on a speculative basis. ${ }^{51}$

Thus LIBOR wasn't untrue in the way that a faulty thermometer is inaccurate. The ritual was performed, and the BBA did generate a very important number on a daily basis. LIBOR was untrue in the sense of dishonest. Asked "what do you believe," players lied. That is, the virtue at issue is not the mechanical one of accuracy, but the moral virtue of honesty. The question is not how to "regulate" the culture from somewhere outside the culture; the question is how do we collectively construct contexts in which we wish to participate, that is, a social capitalism of which we're happy to be members.

Various proposals for LIBOR reform may go some way toward "cleaning up" the LIBOR process, either by reputational cost and the threat of criminal prosecution, ${ }^{52}$ by automatic market mechanisms, ${ }^{53}$ or by enhanced transparency

51 See Wheatley at 6-7.

52 See Wheatley at 22, 74.

53 See Frank Partnoy, Make Banks Pay if They Cheat on LIBOR (July 15, 2012) The Financial Times. 
David A. Westbrook

Culture of Financial Institutions; Institution of Political Economy

February 18, 2013

coupled with ex post sanctions. ${ }^{54}$ And it may well be that such mechanisms would be morally instructive, that is, would cause bank officials to make good faith efforts to conform. At the same time, any reform that seeks more conformity to elite consensus is also by definition conservative. Moreover, as nicely outlined by the Wheatley Review, any alternatives, comprised by different inputs, would entail a somewhat different perspective on the cost of money. And the British banking industry thinks that its perspective is best. Moreover, market participants use this number, so that shows that LIBOR must be fulfilling a demand, right? And besides, these expectations are now wired into countless contracts, with more being made regularly, and radical change might disrupt the markets. Unsurprisingly, the Wheatley Review urges caution. Too much change would not be prudent. So what started out as a first mover advantage and was then buttressed by path dependency has become legitimated, and even needs to be protected. Or, in another language, an innovation has become a habit, which became a custom and eventually a norm attended by the lawgiver, here the British Parliament. Unsurprisingly and as noted above, the lawgiver is disinclined to change.

More than the usual interests of immediate stakeholders are at issue. The global order that allows the operation of credit cards and so much else seems to require LIBOR or something very much like it. Financial institutions need to be able to contractually account for the cost of money, and for this, they require a benchmark. So what is needed is a LIBOR that can be believed, so that confidence in banking will be restored. Banking needs to reform its culture; we must become good sports. It is not at all clear that conservative responses will suffice -- the GFC was largely due to the triumph of economic orthodoxies, and so reaffirmation of such orthodoxies is unlikely to be enough. ${ }^{55}$

54 Rosa M. Abrantes-Metz \& David S. Evans, Replacing the LIBOR with a Transparent and Reliable Index of Interbank Borrowing, (Sept. 2012) Comments on the Wheatley Review of LIBOR Initial Discussion Paper.

55 See generally David A. Westbrook, Out of Crisis: Rethinking Our Financial Markets (Paradigm Publishers, Colorado, 2009). 
David A. Westbrook

Culture of Financial Institutions; Institution of Political Economy

February 18, 2013

For this reason, it makes sense to base financial regulation on the acknowledgment of hierarchy and in particular the power of financial institutions, rather than a spurious claim that financial officials are merely private actors who are to act within bounds arguably set by lawyers, and in rational accordance with the disincentives of reputational cost, as the economists unconvincingly have it. Instead, through a paraethnographic encounter with their regulators, leaders of financial institutions could assist in the design of their own constraints, could shape the terms of their service. And financial leaders, like leaders in other realms, must stand or fall by their success. We may yet imagine LIBOR reform, and what we have learned from the financial crisis more generally, in happy terms. Bankers and their regulators could come to recognize that they are profoundly privileged, and as such, have great obligations. The current culture of disingenuous reporting, pro forma compliance with byzantine and contested rules, and perennially insufficient oversight could be replaced by a more reciprocal relationship in which those who act and those who authorize and ultimately insure speak earnestly and candidly about their worlds. Together these elites could exercise their power wisely, navigate a prudent course forward. Honest conversations about worlds dimly imaginable could lead to good policy in spite of unavoidable uncertainty. The people would be grateful for the custody of their institutions. The ship of state would make good, but not rash, progress.

Even in such a well-governed financial order, sometimes an institution would fail, and the taxing power of the state would have to be used to sustain the viability of the order. At issue, then, would also be the nature of the failure. Was management unworthy? As we have seen, sometimes an institution or an entire industry may lose sight of its own virtues, a story of decadence and decline easily told in London and New York. When the privileged abuse their trust, they would be removed from office, and their responsibility (and attendant wealth and social standing) transferred to more worthy mandarins.

But the privileged would not often abuse their trust. People rarely willingly leave their class for a lower one. Thus a paraethnographic, conversational, and 
David A. Westbrook

Culture of Financial Institutions; Institution of Political Economy

February 18, 2013

reciprocal understanding of the regulatory relationship could go a long way toward making banking a more virtuous enterprise. Presently empty promises to reform could be made serious by establishing contexts in which elites were answerable to other elites, at pain of losing their offices and so their status, and thenceforth having to live small.

Perhaps, but insofar as this provocation is also a ghost story, let us consider two darker courses of regulatory development. In the GFC and lately the LIBOR scandal, the fact that key financial institutions strayed from the commercial virtues traditional in their business (monitoring risk, honesty, and so forth) has led to a concern for culture, meaning the reassertion of traditional norms. That is, the overwhelming response to recent financial crises has been conceptually conservative. But perhaps a conservative response is insufficient? Suppose the world has changed enough that calls for transparency, for obvious instance, will do little to avert the fire next time?

In Macbeth, Macbeth says

I dare do all that may become a man

He who does more, is none. ${ }^{56}$

Macbeth of course begs the question: what becomes a man? What are the virtues appropriate to a Scottish nobleman? So it is with banking. If we think of banking as a business, and our imaginary of "business" is fundamentally based on sole proprietorship, then the purpose of banking is to make money within the bounds of the law. But if we acknowledge that our capitalism is deeply social and banking in particular is custodial and the economy of money is in important respects new, such simple answers will not suffice.

Surely financial markets are in need of reform. But the financial world is necessarily somewhat blind to itself. The Delphic injunction, know thyself, has not

56 William Shakespeare, Macbeth (McMillan \& Co., London, 1871) 17. 
David A. Westbrook

Culture of Financial Institutions; Institution of Political Economy

February 18, 2013

gotten any easier. So it is hard for the financial policy community to think deeply about what kind of financial markets we as a society want, for student debt or housing or anything else.

These are essentially aesthetic, in the philosophical sense of the word, questions. Out of Crisis used the metaphor of games to talk about market regulation. ${ }^{57}$ In both markets and games, different kinds of rules favor different kinds of competition, and foster different kinds of outcomes. So what kind of rule sets, informing what sorts of participation, do we want banking to have? In what kind of game do we want Barclays and its kin to be good sports?

As suggested above, we can imagine a world in which bankers and their regulators have long, honest conversations about how different kinds of financial games -- institutions and their markets -- should be played, and what were the advantages and risks attendant upon this or that way of doing things. That would not be our current situation. There is reason to be skeptical about the capacity of elites in advanced markets to have the sort of publicly minded conversation suggested here. It is worth remembering that Macbeth is a tragedy. Macbeth overreaches, and there has been a lot of that in recent years, at Barclays and elsewhere. So although we may imagine what custodial regulation would look like, it may be difficult if not impossible to achieve in fact. The imagination of banks as "private" actors who are monitored by "the government" is simply too deeply embedded. And in due course, we will again watch "private" actors do in principle unnecessary harm to their, and our, communities.

Our situation may be tragic in another sense. Cultures and institutions may themselves be wrong in the very exercise of their virtues. Americans like to believe that if one does the right thing, things will go well. But the tragic perspective is that one may do the right thing, or what is honestly believed to be right, and things may go very badly. It is not difficult for an American Southerner of German descent to recall that nations may march off to misguided wars. As already noted, a great deal

57 See Westbrook, Out of Crisis, Chapter 7 (Metaphors For Thinking Socially About Capitalism). 
David A. Westbrook

Culture of Financial Institutions; Institution of Political Economy

February 18, 2013

of the GFC was due not to misfeasance but the enthusiastic use of the substantial accomplishments of post-war finance. Just suppose, contra the Introduction, that we need not enforce or return to the virtues of finance, but that the virtues of finance are just the danger we should fear?

More specifically, let us assume that, through considerable collective efforts, LIBOR is reformed (and we agree on global accounting standards and an international insolvency regime) and, as a result of such policy diligence, faith in global banking is renewed. Presumably this will strengthen and extend our financial culture. Would this be a good thing?

In the US, banks are concentrated, inequality is stratospheric by our own historical standards, and unemployment is high while growth is slow. Perhaps worst of all, especially after Citizens United, political outcomes are openly discussed as assets. ${ }^{58}$ In Europe, Martin Wolfe reports that banked assets are equal to 350\% of GDP. ${ }^{59}$ Due to demographics and otherwise, prospects for growth are dim. Wolfgang Munchau speculates that banking union, and ultimately the institutional apparatus required to secure European financial institutions and national budgets, will supersede both the member states and European institutions. 60 This would amount to a Europe 2.0, explicitly enacted to preserve finance. That is, finance will have become constitutional.

The reemergence of naked privilege -- defined in terms of bureaucratic standing rather than noble birth -- may be a change of the longue duree. Perhaps we are watching Marx backwards, the slow motion and technocratic victory of a new sort of financial class, rather than the revolutionary violence of the proletariat. It is

58 Citizens United v. Federal Election Commission (2010). My thoughts on the decision are available in, 'If not a commercial republic? Political economy in the United States after Citizens United.' See David A. Westbrook, 'If not a commercial republic? Political economy in the United States after Citizens United,' (2011) 1 U. Louisville L. Rev. 50.

59 See Martin Wolf, You Can't Measure An Economy's Performance on Recovery Alone (October, 2012) The Financial Times.

60 See Wolfgang Munchau, The Eurozone Crisis Is Not Finished (Febrarury 3, 2013)

The Financial Times. 
David A. Westbrook

Culture of Financial Institutions; Institution of Political Economy

February 18, 2013

not at all clear how desirable the society under construction is, even if recent experience in airports ("Our platinum, diamond and gold passengers may now board through the priority boarding lane") suggests it may be an inevitable corollary of doing business on a global scale. But surely nobody with democratic republican sentiments can welcome such developments? In this much, at least, the Occupy Wall Street protesters were correct.

Nor is it clear how stable a global economy of money might be. The number of financial crises in recent years gives one pause. Surely there must be practical limits to the level of abstraction, the scale, interconnection, and general complexity of our institutions? And would not LIBOR reform, indeed would not almost any successful financial reform, only increase the scale and complexity of our institutions, with the attendant alienation and danger of catastrophe? From this perspective, financial policy may well be a noble enterprise; tragedy requires nobility. So perhaps the regulation of financial institutions is like worrying about the steering gear on the Titanic. Either we fail to fix it, and remain adrift. Or we succeed in fixing it, and hasten on.

Even then, one should try to remember, some folks always survive. 